\title{
Conspicuous Strategies in Teaching Expressive Writing: A Quantitative Study Comparing Two Approaches to Process Writing
}

\author{
Jennifer Fontenot I Karen J. Carney I Kay Hansen
}

A process-writing approach $(B W)$ with novel concepts was developed by the authors to teach writing to elementary-level students. They believed the BW approach was effective but was particularly effective for special-needs students. Consequently, they decided to quantitatively test these assertions. Instead of testing students taught using the BW approach against a control with no special training, the authors chose to compare BW to a control trained using a widely-taught process-writing approach $(P W)$. Rather than test null hypotheses that assert that $B W$ and $P W$ are equally effective for all students and that $B W$ and PW were equally effective with special-needs students and general education students, the authors decided to test two alternative hypotheses: 1) The BW intervention is significantly better than the PW intervention for all students. 2) Specialneeds students show significantly more improvement than general-education students for both interventions but special-needs students trained with BW show more improvement than those trained with $P W$.

The standardized Written Expression subtest of the Wechsler Individual Achievement Test II (WIAT-II), Form A, was used to quantify achievement. The WIAT was developed by Dr. David Wechsler and has been widely used to quantify academic achievement of people in many areas including written expression.

The BW and PW groups were tested using the WIAT before and after being trained to write for four months using the BW and PW approaches. Student growth was analyzed for general-education and special-needs students for each intervention. Highly significant results confirmed the hypotheses regarding the effectiveness of the BW approach.

The educational challenge to bring all children to higher levels of competence in their academics is daunting. In 2001, the No Child Left Behind Act (NCLB) was passed (www.nclb.gov) calling on educators to use research-validated strategies in order to effectively teach an ever-increasing diverse population of students. Elementary and middle schools across the nation are engaged in the pursuit of finding the best ways to teach the foundation skills of reading, writing, and arithmetic at a faster pace than ever before. Educators continue to deliberate which teaching strategies will improve student academic skills levels across the curriculum. School districts across the nation are seeking innovative research-based teaching strategies to improve student performance. 


\section{HOW ARE OUR CHILDREN DOING?}

There is a plethora of anecdotal evidence attesting to poor writing skills from those that regularly read writing selections prepared by students at all levels from first graders to doctoral candidates as well as those in the corporate world that read reports prepared by corporate employees. This anecdotal evidence has been confirmed quantitatively for students in grades 4,8 and 12 through testing done by the National Assessment of Educational Performance (NAEP) since 1969. NAEP provides a nationally representative indicator of how the nation's students are achieving in key academic subjects including writing. These tests provide information that can help to determine long term trends educationally. The NAEP is the largest national assessment of academic skills for American students. In in a recent study conducted by NAEP in 2011, the percent of students in the 8th grade achieving at or above proficiency in writing was $27 \%$. (NAEP, 2011). The remaining 73\% (almost three quarters) of 8th grade students were functioning at unacceptable basic or below basic levels of performance.

The most recent NAEP test for writing at the 4th grade level was conducted in 2012. These data were reported somewhat differently than the 8th grade data in 2011. Some 4th graders were tested using a 30 minute prompt and others were tested using a 20 minute prompt. In both cases, however, the results were actually worse than the unacceptable levels of performance demonstrated by the 8th graders in 2011. For the 30 minute prompt only $14 \%$ of 4th graders performed at a proficient or aboveproficient level, $47 \%$ performed at a basic level and $39 \%$ performed at a below-basic level. For the 20 minute prompt only $6 \%$ performed at a proficient or above-proficient level, $50 \%$ performed at a basic level and $44 \%$ performed at a below-basic level (NAEP, 2012).

\section{WHAT IS KEEPING OUR STUDENTS FROM BECOMING PROFICIENT WRITERS?}

In order to increase proficiency in writing for all students, it is imperative to understand what is known about student learning of writing, as well as the teaching of writing and what characteristics inhibit student success. From the perspective of student learning, there is an ever-widening spread of cultures, languages, abilities, and other characteristics in a typical classroom (Gollnick \& Chinn,
2012). Not only do students vary in their native languages, but students also vary in their languageprocessing abilities. Students do not necessarily share the same background or vocabulary. Some may have difficulty relating to a writing topic and over time become dependent on the teacher (Swanson, Harris, \& Graham, 2013). Students with disabilities may struggle with writing activities because they may know less than their classmates about the steps of writing; they are not proficient in planning and/or organizing their writing (Graham \& Harris, 2005), or with mechanics and spelling (Gargiulo 2014).

Overall, research has shown that students with learning disabilities or other special needs often struggle more with the subject of writing than their normally achieving peers (Graham \& Harris, 2005).

Elements in the teaching of writing, although well intentioned, can also impede student proficiency in this area. Swanson, Harris, \& Graham (2013) proposed that instruction may be one reason students struggle with writing because too little time is provided for writing instruction within the K-12 literacy curriculum. Zumbrunn and Krause (2012) discussed this issue within a qualitative study that explored the observations of leaders in the field of writing instruction. The principle challenges that were identified in that study were inconsistency of practice, lack of extended time to commit to the process of writing in the classroom and a low expectation for the amount of writing produced by students within any given instructional unit.

\section{PROCESS WRITING}

One positive change in writing that has occurred in the last forty years is that writing has moved from a product-oriented model, focusing primarily on mechanics and grammar, to a process-oriented model that includes content and movement through steps or writing stages (Cooper, 2005; Routman, 2000; Ruddell, 2005; Tompkins, 2011). In its most basic format, process writing involves teaching students to plan, write, and revise. It also can involve the establishment of a comfortable environment for self-expression which many teachers refer to as "Writer's Workshop" time in a classroom. By establishing a supportive atmosphere for writing, students work as a writing community proceeding through multiple phases or stages at their own pace 
in order to express their thoughts in writing in a meaningful manner. This process can also link reading, writing, speaking, and listening activities for a comprehensive approach to self-expression (Cooper, 2005; Routman, 2000; Ruddell, 2005; Tompkins, 2011).

Even though process writing has benefited many students in the classroom, some students need additional systematic instruction in writing in order to be successful (Graham, Harris \& Mason, 2008). For students who are socio-economically at risk and/or are disabled, the complex processes involved in becoming skilled writers are difficult (Lane, Harris, Graham, Weisenbach, Brindle, Morphy (2008). There is a strong body of high-quality research, however, which supports quality instruction, including writing instruction.

\section{RESEARCH ON BEST PRACTICE IN TEACHING}

In 1994, the National Center for Improving the Tools of Educators (NCITE) at the University of Oregon published a technical report called, Executive Summary of the Research Synthesis on Effective Teaching Principles and the Design of Quality Tools for Educators (Ellis, Worthington, \& Larkin, 1994). In that report, ten effective teaching principles that were supported by research were laid out. Highlights of those ten principles include active engagement during instructional tasks; direct teaching by the teacher; and scaffolding, strategic instruction, and explicit instruction to promote independence and self-regulation, and teaching sameness.

These principles can be applied to improving writing instruction. By 1998, a smaller list of effective teaching strategies accommodating diverse learners was offered by Kameenui \& Carnine (1998). Again associated with the National Center to Improve the Tools of Educators (NCITE) from the University of Oregon, the six accommodations included: a) big ideas; b) conspicuous strategies; c) primed background knowledge; d) mediated scaffolding; e) judicious review; and f) strategic integration.

In 2008, Ideas that Work, from the Office of Special Education Programs (OSEP), sponsored a website called The Access Center (www.k8accesscenter.org). The web site provides strategies to improve student access to the K-8 general education curriculum classifying them on a continuum depending upon their research base. Specific strategies have been given a "green light" (evidencebased practices) or a "yellow light" (promising practices).

Two instructional practices that are related to the teaching of writing that have received green lights for being evidence based are Direct Instruction (explicit instruction), and peer-assisted learning strategies (PALS). Direct instruction is a fast paced, structured, repetitive, teacher-directed method of instruction. It is a systematic, explicit, intense interaction between the teacher and student(s), with frequent assessments and support for accurate learning. Peer-assisted learning strategies allow for pairings of students in coach and player roles.. These pairs interact in structured cooperative activities, supporting each other through frequent oral interaction, feedback and reinforcement. A third learning tool that received a green light for its evidence base in supporting instruction is the use of cognitive or meta-cognitive strategies.

These techniques or rules help students acquire, store, use, and retrieve information they have learned, thereby supporting students who lack organization, have difficulty with abstract concepts, or have memory and communication delays.

\section{RESEARCH ON BEST PRACTICE IN WRITING INSTRUCTION}

Key elements from these evidence-based teaching strategies appear as components in the research specifically for writing instruction. A metaanalysis of over 15 years of research-based examples of teaching writing to students with learning disabilities was conducted by Gersten and Baker (2001). They found three broad concepts essential in teaching writing, two of which employ explicit instruction: a) explicitly teaching the steps of the writing process (planning, writing, and revision) and b) explicitly teaching the conventions of writing genres. The final broad concept identified in this meta-analysis involved improving quality of writing through ongoing guided feedback.

Cognitive and meta-cognitive strategies also appear in research for improved writing instruction. There are more than 30 studies showing the value of a meta-cognitive approach called SelfRegulated Strategy Development (SRSD) for both normally achieving students as well as those with learning disabilities (Graham \& Harris, 2005). 
SRSD has supported writing improvement across a variety of genres, helping students in four main areas of writing: quality of writing, knowledge of writing, approach to writing, and self-efficacy (belief about one's own ability to perform). The six stages in this approach involve: a) activating background knowledge; b) discussing the strategy; c) modeling it; d) memorizing it; e) supporting it, and f) performing it independently.

Research has supported the use of other strategies using a cognitive approach. Swanson, Harris, Graham (2013) found that Cognitive Strategy Instruction in Writing helped 7th grade students with learning disabilities to improve their writing performance. This involved three guiding principles: a) students need to understand that writing is a process including planning, organizing, writing, editing, and revising; b) immature writers need "think aloud" support from the teacher to help scaffold instruction to match the level of the student; and c) there is a social feature of writing that involves the importance of writing for authentic purposes and real audiences. Shapiro (2011) added to the research on cognitive strategies by finding that students with disabilities can succeed in writing multi-paragraph themes enabling them to reach proficiency on state tests when taught using explicit writing strategies such as paragraph writing, error monitoring, InSPECT (spelling), and theme writing.

\section{STATEMENT OF PROBLEM}

For over ten years, there has been a growing body of research to validate approaches that can support students in becoming better writers. However, state and national testing results show that many students still struggle to demonstrate proficiency in expressive writing, especially those at risk socio-economically and with disabilities. A problem exists bridging the research findings to best practices of teaching writing in the classroom. Most teachers are provided with district/ state writing curricula and often receive training in using process writing; however, they do not necessarily receive training on how to deliver instruction using research-based teaching strategies. Specifically, teachers face a challenge to identify a way to systematize those strategies and integrate them into a comprehensive and step-by-step process for teachers to use when teaching writing in inclu- sive classrooms. Once systematized, this strategic approach needs to be compared with the current standard process writing approach, to assess if, in fact, general education students as well as those at risk and/or with disabilities benefit by these practices (Kameenui \& Carnine (1998). Adding to this challenging situation is the fact that many teachers struggle with their own self-efficacy as writers, and therefore may to resistant to innovative and integrative processes in instruction (Zumbrunn \& Krause, 2012).

\section{PURPOSE STATEMENT}

The purpose of this quantitative quasi- experimental study is to demonstrate the results of just such a comparison, showing student growth in expressive writing using two instructional approaches to process writing. An instructional intervention involving the delivery of a systematic approach involving explicit instruction in writing phases, with conspicuous strategies for helping students to be actively engaged in the learning process will be compared to a standard writing approach used in many K-8 classrooms in the nation.

\section{RESEARCH QUESTIONS AND HYPOTHESIS}

As stated in the abstract, the null hypotheses for this study assert that: 1) BW and PW are equally effective for all students and: 2) BW and PW were no more effective with special-needs students than with general education students. Rather than test the null hypotheses directly (because previous classroom experience provided qualitative evidence that the null hypotheses should be rejected), the authors decided to test two alternative hypotheses that assert that 1) BW is significantly more effective than PW as an instructional intervention for teaching writing to both general-education and special-needs students and: 2) BW and PW are more effective with special-needs students than with general-education students and that BW is significantly more effective than PW for specialneeds students. These hypotheses are summarized in the following research questions: 1) Does the BW intervention provide significantly better results than the PW intervention for both generaleducation students and special-needs students? 2) Do special-needs students show significantly more improvement than general-education students for both interventions and do special-needs students 
trained with BW show significantly more improvement than special-needs students trained with PW?

\section{METHOD}

\section{PARTICIPANTS}

This quantitative quasi- experimental study investigated a total of 133 sixth grade students from one mid-western school district, three classes in School A and three classes in School B. Initially, there were a total of 150 students who participated in this study. Seventeen students were eliminated due to missing data. This was primarily a result of student absence on days when data were collected. The sixth grade students in both schools were inclusive, with both general education students and those identified as special education or at risk being represented in the classroom.

Special education students were defined as those who were officially identified with a disability and were eligible for special education support. At risk students were identified by the state formula based on financial need (students who qualified for free or reduced-price school lunches). School A had 31 general education students and 34 special education/at risk students (total of 65 students), while School B had 43 general education students and 25 special education/at risk students (total 68 students). There were 37 males and 28 females in School A, and 37 males and 31 females in School B. School A had 10 African American students, 54 Caucasian students and one Hispanic student; for School B there were 10 African American students and 58 Caucasian students.

This study also included six classroom teachers who provided instruction in the writing process. The teachers in School A included one male and two females, with an average of six years of teaching experience. In addition, all teachers in School A had a Masters Degree in Education. Two of these teachers were Caucasian and one Asian. The teachers in School B included three females, with an average of 18 years of teaching experience. Two of the teachers in School B held a Master's Degree in Education while the third teacher held a Bachelor's Degree in Education. All three teachers were Caucasian.

\section{WRITING INSTRUCTION INTERVENTIONS}

Teachers in School A were taught a set of conspicuous and interactive strategies to assist in teaching their standard curriculum, which included a graphic organizer for writing paragraphs called a blueprint, hereafter referred to as blueprint writing (BW). BW training consisted of six sessions totaling 10 hours. Emphasis was given to teaching process writing stages that included explicit teaching of writing vocabulary, scaffolding that included multi-sensory experiences and languagerich brainstorming, visual graphic organizers, and peer-assisted learning in pre-writing and editing.

Teachers in School B used the district's standard process-writing program (PW). In order to assure teachers in School B had a thorough understanding and commitment to these teaching strategies, they were re-trained in this process writing curriculum. They received a three day workshop which consisted of 21 hours in PW instruction. This additional teacher training assured that both groups of teachers were current in their respective writing strategies.

\section{PROCEDURE}

Permission to implement the study was obtained from the principals of the two elementary schools selected to be in the study. Permission to participate in the study was obtained from the parents of the 6th grade students in both schools. Data were analyzed only from those students for whom parental permission was granted.

The study plan required that the Written Expression subtest of the WIAT-II, Form A, be taken by all study participants as the initial step in the process. For the next four months, School A implemented the blueprint writing approach (BW) and School B implemented the standard process writing approach $(\mathrm{PW})$. At the end of the four month period, a post-test of the Written Expression subtest of the WIAT-II, Form B, was administered to the same students.

Teacher training took place prior to the start of the study. Teachers had access to materials and support for the specific approach they were implementing. In addition, teachers were asked to complete forms that provided information related to their teaching experience.

\section{ANALYSIS}

The study questions identified for this research project were: 1) Does the BW intervention provide 
significantly better results than the PW intervention for both general-education students and special-needs students? 2) Do special-needs students show significantly more improvement than general-education students for both interventions and do special-needs students trained with BW show significantly more improvement than special-needs students trained with PW?

To determine the answers to these questions, pre-test and post-test scores were analyzed to compare aggregate differences between the two instructional approaches for expressive writing (School A=BW, School B=PW), for two subgroups of students (general education students and special education/at risk students). A formal analysis (ANOVA) was then performed to determine the statistical significance of the differences found.

After the WIAT-II subtests were scored, data were collected and assembled into an SPSS data base. The specific data for each student within the SPSS data base included school identification, student identification, student education classification (special/at risk, general) and composite raw scores from both WIAT-II subtests. After entering the raw data, the pre-test and post-test data were standardized using the WIAT-II Grade-Based Standard Scores tables. Pre-test data were standardized using the grade 6 'Winter' table and post-test data were standardized using the grade 6 'Spring' table.

\section{RESULTS}

\section{COMPARISON OF STANDARD SCORES FROM PRETESTS AND POSTTESTS}

Since the purpose of this study was to compare mean growth over a four month period, the two schools did not have to be matched in pre-test scores. Table 1 presents the mean pretest and posttest standardized scores for both student types receiving both intervention treatments. By using the standardized scores, which by definition take into account the maturation of students over time, the difference between the pretest and posttest scores were used to calculate the improvement in writing for each student over the four months of this study. Table 1 shows the aggregate mean growth of students as measured by the change between WIAT-II pretest and posttest scores, suggesting that general education students improved in their writing ability over the four months in both treatment conditions.
The special education/at risk students in the BW treatment showed considerably more growth than those in the PW treatment over this same period.

\section{STATISTICAL SIGNIFICANCE OF RESULTS}

In order to determine the significance of these data, researchers used a two-factor independentgroups ANOVA procedure. Each factor in the ANOVA analysis had two categories. Factor One was identified as the Intervention Method. The two categories for Factor One corresponded to the BW and PW writing strategies. Factor Two was identified as Student Type. The two categories for Factor Two corresponded to the special education/at risk and the general education student populations. The variable analyzed was the pre-test and posttest score difference for each student. The results are found in Table 2.

\section{BETWEEN AND WITHIN GROUP DIFFERENCES}

The overall test between intervention types showed that growth in standard scores between intervention types was highly significant $(\mathrm{F}(1,130)=$ $67.78, \mathrm{p}<.01)$ as was the interaction between intervention types and student types $(\mathrm{F}(1,130)=11.88$, $\mathrm{p}<.01)$. The difference between student types was not significant $(\mathrm{F}(1,130)=.443, \mathrm{p}>.05)$. This was further analyzed using a Bonferroni post hoc comparison. For the special education/at risk student population, the difference between being instructed with the BW and the PW interventions was significant at the $\mathrm{p}<0.01$ level $(\mathrm{t}=7.791)$. Using the aggregate mean differences in Table 1, it is apparent that the growth of the special education/at risk students receiving the BW intervention outperformed their counterparts receiving the PW intervention. The difference between the BW and PW interventions for the general education student population was also significant at the $\mathrm{p}<0.01$ level $(\mathrm{t}=4.355)$.

Again, the growth in writing for general education students receiving the BW intervention was statistically higher than for that same student group receiving the PW intervention. The difference between the special education/at risk and the general education student population receiving the BW intervention was statistically insignificant $(\mathrm{t}=0.639)$, showing that there was not a significant difference between student subgroups in this intervention (improvement scores were similar). The difference between the two student populations receiving the 
PW intervention was statistically significant at the $\mathrm{p}<0.01$ level $(\mathrm{t}=3.451)$, as the general education students' improvement was significantly more than the special education/at risk subgroup. Table 3 shows the results of this post hoc comparison.

See Table 3.

Addressing the first of the two study questions, is one intervention superior to the other for all students, the answer is yes. The statistical analysis showed a significant difference between intervention types, with growth in writing from students receiving the $\mathrm{BW}$ intervention superior to the $\mathrm{PW}$ intervention for combined student subgroups. The second study question asked whether special-needs students performed better than general-education students for both interventions and whether special needs students receiving the BW intervention performed better than special-needs students receiving the PW intervention. The answer for the first part of this question is yes for the BW intervention and no for the PW intervention. The answer for the second part of this question is yes, the special-needs students receiving the BW treatment performed substantially better than those receiving the PW treatment at risk.

\section{DISCUSSION}

Within this study, general education students were seen to improve in their writing abilities using the standard process writing (PW) approach and improved at even a quicker pace if the conspicuous strategies and explicit instruction of the BW intervention were incorporated into the instruction. Further, the study showed significant growth in writing for students at risk and/or with disabilities who were taught using conspicuous strategies, and no significant growth for this population using only the standard process writing. It is no surprise that using research-validated strategies to teach to the wide span of abilities in inclusive classrooms should result in improved performance. The difficulty lies in finding a systematic way to incorporate those strategies into instruction, so that busy teachers can add them into their instructional repertoire.

In this study, a specific approach to incorporating evidence-based strategies was taught to the teachers using the BW intervention. This approach was in instructional delivery. It did not change the curriculum standards or expectations. For educators responsible for writing instruction, this study confirms that the systematic, conspicuous strategies in the BW approach, taken from research-validated techniques, can result in significant student progress over the standard process writing approach. This has implications for helping teachers provide effective instruction to students of all abilities, which first and foremost will benefit these students individually to become competent writers.

As classrooms of children increase in their writing ability, their growth will be reflected in improved state high-stakes testing scores and ultimately on tests such as the NAEP. Because the results for the BW approach are particularly valuable in relation to at risk learners, this is especially meaningful as this population needs the most effective educational interventions in order to become proficient writers as well as to meet the requirements of NCLB and the various state high-stakes tests.

\section{THE BLUEPRINT WRITING (BW) APPROACH}

The BW approach was designed to incorporate conspicuous strategies into the explicit teaching of the writing process, so that oral language is stimulated before the written word, via vocabulary building activities and multi-sensory experiences related to the writing topic. Graphic organizers are used to support vocabulary development and add visual support for spelling of key words and memory aids for concepts discussed. Even more, the color-coded blueprint form for organizing ideas into paragraphs provides concrete and visual support for students who require scaffolding at that level, yet are not required for those students who understand that process.

The teacher is taught how to use explicit instruction in highly interactive lessons, and to allow for students to "talk aloud" their stories before writing. Peer assisted learning is involved, as students "talk" their paragraphs out to partners before writing and during editing. Editing is done three times: first, when the student uses the class-created editing rubric on his/her own writing, then for peer editing, and finally for teacher conferencing. This allows for individualized instruction at each student's own level of understanding the writing process.

Finally, all writing is given an authentic outcome by the publishing process, so that students know they are writing for a purpose. The BW 
strategies can be applied to any school district curriculum as they are designed to take the researchvalidated techniques and put them into a format easily adopted by classroom teachers.

\section{NEED FOR SYSTEMATIC APPROACHES TO SUPPORT TEACHER INSTRUCTION}

This study does not negate the value of a standard writing process format in teaching expressive writing to students. Instead, it highlights the importance of embedding evidence-based teaching strategies into that instruction. It is important for schools to have a writing curriculum with a scope and sequence for teaching the skills and knowledge needed for students to become good writers. It is also important for teachers to be trained in the use of a writing process, and on how to talk about good writing with students using a shared vocabulary. This training should also include assessing student writing; but, because writing is such a complex skill, the use of research-validated teaching strategies needs to be embedded in the instruction to support learners of all types to find a concrete way to understand and build their skills. This study demonstrates that this element can be systematized and added into the instruction of expressive writing resulting in improved outcomes for all students in their writing ability.

\section{LIMITATIONS OF THIS STUDY}

As with any study of this type, resources of time and personnel were limited. It would have been desirable to test multiple grades in multiple schools in a variety of districts throughout the country using a perfectly matched sample of students. Unfortunately this was not possible due to a variety of constraints. On the other hand, the sample was large enough and the results were significant enough that expectations for writing improvement can be generalized with a high level of confidence.

Another limitation in this study involves the teachers for each instructional intervention. Although the participants in each intervention were reasonably matched, the teacher characteristics show a disparity. Teachers in School A (BW intervention) were less experienced (6 years) than those in School B (PW intervention), who had 18 years of experience, on average, yet the students in School A outperformed those in School B. The study did not include observations of their styles of teaching.
Both groups of teachers were trained/retrained in their approach just prior to the four-month study period. However, the difference between the two groups of teachers may impact the results.

Finally, this study used an intervention that involved a composite process, not a single teaching strategy. Some might want to know which teaching strategies accounted for the most student learning. Although the strategies embedded in the BW approach were taken from research-validated techniques, it would not be possible to tease out which of the individual techniques accounted for the growth seen.

\section{FUTURE RESEARCH}

With the evidence available regarding instructional practices that support student learning, future research should focus on how to embed those strategies into systematic subject instruction. This involves more than just teaching the strategies in pre-service and in-service trainings. Teachers are busy every day teaching their classes and correcting papers and planning lessons at night. They benefit from having systematic programs to teach different subjects laid out, which should include the evidence-based strategies as to possible ways to deliver that instruction. The evidence that a conspicuous strategy approach, such as the blueprint writing approach, is successful with both general and special education/at risk populations should be replicated in a variety of settings and at various grade levels to add value to the findings in this study. Various combinations of evidence-based strategies should be investigated combining, for example, cognitive strategies with highly interactive vocabulary instruction.

In addition, upon review of fifty research studies investigating writing instruction, more research is needed to address the barriers that prevent teachers from incorporating these strategies into their daily instruction.

For more information on these strategies, contact the authors of this study. 


\section{REFERENCES}

Cooper, J.D. (2005). Literacy: Helping children construct meaning (4th ed.). Boston:, MA: Houghton Mifflin.

Ellis, E.S., Worthington, L.A., \& Larkin, M.J. (1994). Executive summary of the research synthesis on effective teaching principles and the design of quality tools for educators. (Technical Report No. 6). Eugene, OR: University of Oregon, Retrieved from http://idea.uoregon.edu/ ncite/

Gargiulo, R.M. (2014). Special education of contemporary society: An introduction to xxceptionality. (5th ed.). Thousand Oaks, CA: Sage Publications.

Gersten, R., \& Baker, S. (2001). Teaching expressive writing to students with learning disabilities: A meta-analysis. The Elementary School Journal, 101 (3), 251-272.

Gollnick, D.M. \& Chinn, P.C. (2012). Multicultural education in a pluralistic society, (9th ed.). New York, NY: Merrill.

Harris, K.R., Graham, S., \& Mason, L.H. (2003). Self-regulated strategy development in the classroom: Part of a balanced approach to writing instruction for students with disabilities. Focus on Exceptional Children, 35 (7), 1-16.

Graham, S., \& Harris, K. R. (2005). Writing better: Effective strategies for teaching students with learning difficulties. Baltimore, MD: Brookes.

Harris, K. R., Graham, S., Mason, L. H., \& Friedlander, B. (2008). Powerful writing strategies for all students. Baltimore, MD: Brookes. www.nclb.gov

Kameeuni, E.J., \& Carnine, D. (1998). Effective strategies that accommodate diverse learners. Upper Saddle River, $\mathrm{NJ}$ : Prentice Hall.

Lane, K. L., Harris, K. R., Graham, S., Weisenbach, J. L., Brindle, M. \& Morphy, P. (2008). The effects of Self-Regulated Strategy Development on the writing performance of secondgrade students with behavioral and writing difficulties. Journal of Special Education, 41,234-253

Routman, R. (2000). Conversations: Strategies for teaching, learning, and evaluating. Portsmouth, NH: Heinemann.

Ruddell, R.B. (2005). Teaching children to read and write: Becoming an effective literacy teacher (4th ed.). Boston, MA: Allyn \& Bacon.

Shapiro, E. (2011). Academic skills problems: Direct assessment and intervention (4th ed.) New York, NY: The Guilford Press.
Swanson, H.L., Harris, K. R., \& Graham, S. (2013). Handbook of Learning Disabilities (2nd ed). New York, NY: The Guilford Press.

Tompkins, G.E. (2011). Teaching writing: Balancing process and product. (6th ed.) Upper Saddle River, NJ: Merrill.

National Center for Education Statistics. National Assessment of Educational Progress (NAEP), 2011. Writing Assessments. The Nation's Report Card: Writing Highlights 2011. Retrieved from: http://nces.ed.gov/nationsreportcard/pubs/ main2011/2012457.asp

Zumbrum, S. \& Keegan, K. (2012). Conversations with leaders: Principles of effective writing instruction. The Reading Teacher. 41, 346-353

Table 1

Pretest, Posttest, and Mean Difference Statistical Parameters

\begin{tabular}{cccccccc}
\hline & & \multicolumn{2}{c}{ Pretest } & \multicolumn{2}{c}{ Posttest } & \multicolumn{2}{c}{ Difference } \\
\cline { 3 - 8 } School & $\begin{array}{c}\text { Student } \\
\text { Type }\end{array}$ & Mean & SD & Mean & SD & MD & SD \\
\hline A (BW) & $\begin{array}{c}\text { General } \\
\text { Ed }\end{array}$ & 96.9 & 11.3 & 108.4 & 12.5 & 11.48 & 8.1 \\
\hline B (PW) & $\begin{array}{c}\text { General } \\
\text { Ed }\end{array}$ & 103.1 & 12.0 & 108.7 & 13.0 & 5.67 & 4.9 \\
\hline A (BW) & $\begin{array}{c}\text { SpEd/At } \\
\text { Risk }\end{array}$ & 75.1 & 7.8 & 87.5 & 10.1 & 12.38 & 4.1 \\
\hline B (PW) & $\begin{array}{c}\text { SpEd/At } \\
\text { Risk }\end{array}$ & 74.1 & 7.3 & 74.8 & 8.6 & 0.76 & 5.2 \\
\hline & & Table 2 & & & \\
\hline
\end{tabular}

Two Way Analysis of Variance (ANOVA) for Effects of Intervention Type, Student Types, and Subjects within Interventions/Student Type Groups

\begin{tabular}{ccccc}
\hline & SS & MS & $F(1,130)$ & $p$ \\
\hline $\begin{array}{c}\text { Intervention } \\
\text { type }\end{array}$ & 2,172 & 2,172 & 67.78 & $<0.01$ \\
\hline Student type & 13.89 & 13.89 & 0.43 & $>0.05$ \\
\hline Interaction & 381.01 & 381.01 & 11.88 & $<0.01$ \\
\hline $\begin{array}{c}\text { Subjects } \\
\text { within } \\
\text { intervention/ } \\
\text { student type } \\
\text { groups }\end{array}$ & 4167.70 & 32.06 & & \\
\hline
\end{tabular}




\begin{tabular}{ccccc}
\hline \multicolumn{5}{c}{ Table 3 } \\
Bonferroni Post Hoc Comparisons on Interaction & \\
\hline Variable & Mean 1 & Mean 2 & $\mathrm{t}$ & $\mathrm{p}$ \\
\hline $\begin{array}{c}\text { Special ed/ } \\
\text { at-risk }\end{array}$ & 12.38 & 0.76 & 7.79 & $<.01$ \\
\hline $\begin{array}{c}\text { General } \\
\text { education }\end{array}$ & 11.48 & 5.67 & 4.36 & $<.01$ \\
\hline BW & 12.38 & 11.48 & 0.64 & no \\
\hline PW & 0.76 & 5.67 & 3.45 & $<.01$ \\
\hline
\end{tabular}

\section{Author Biographies}

Jennifer A. Fontenot is a 35-year veteran teacher and consultant in public education and an associate professor at Grand Canyon University in the College of Education. Jennifer is a Pearson Education Company and Corwin publisher. She has been awarded Teacher Educator of the Year in her home state, Michigan. In addition, her writing frameworks leads the State of Michigan as the only published and state approved writing program for English Language Learners.

Karen J. Carney is a retired professor of special education from Eastern Michigan University. Karen's career in education extends over 30 years, as a teacher and consultant for students with emotional and behavior disorders, a primary teacher, an elementary principal and a special education director. She has worked in public schools in Connecticut, in Wyoming, and outside of Sydney, Australia.

Dr. Kay Hansen received her Master's degree as a Reading Specialist and her PhD in Curriculum and Instruction/ Language and Literacy from Arizona State University. She has worked with preservice teachers as a faculty member and department chair at Grand Canyon University. She also served as both the Assistant Dean of the College of Education and the Chair of the Masters of Reading program.

Kay has worked in developing curriculum for struggling readers and writers as well as contributed as a consultant for high school teachers looking for strategies to increase their students' content area literacy. Her passion is to ensure that all students have access to the tools necessary to become fluent readers and writers. 